Pesq. Vet. Bras. 37(4):368-378, abril 2017

10.1590/S0100-736X2017000400011

\title{
In vitro antimicrobial activity of the organic extract of Cladonia substellata Vainio and usnic acid against Staphylococcus spp. obtained from cats and $\operatorname{dogs}^{1}$
}

\author{
Jusciêne B. Moura ${ }^{2 *}$, Agueda C. de Vargas ${ }^{3}$, Gisele V. Gouveia ${ }^{2}$, João J. de S. \\ Gouveia², Juracy C. Ramos-Júniorr ${ }^{4}$, Sônia de A. Botton³ ${ }^{3}$ Eugênia C. Pereira ${ }^{5}$ \\ and Mateus M. da Costa ${ }^{2}$
}

\begin{abstract}
Moura J.B., Vargas A.C., Gouveia G.V., Gouveia J.J.S., Ramos-Júnior J.C., Botton S.A., Pereira E.C. \& Costa M.M. 2017. In vitro antimicrobial activity of the organic extract of Cladonia substellata Vainio and usnic acid against Staphylococcus spp. obtained from cats and dogs. Pesquisa Veterinária Brasileira 37(4):368-378. Laboratório de Microbiologia e Imunologia Animal, Universidade Federal do Vale do São Francisco, Campus de Ciências Rurais, BR-407 Km 12, Lote 543, Projeto de Irrigação Nilo Coelho s/n, "C1", Petrolina, PE 56300-990, Brazil. E-mail: juscikoelho@hotmail.com

Cladonia substellata Vainio is a lichen found in different regions of the world, including the Northeast of Brazil. It contains several secondary metabolites with biological activity, including usnic acid, which has exhibited a wide range of biological activities. The aim of this study was to evaluate the in vitro antimicrobial activity of the organic extract of $C$. substellata and purified usnic acid. Initially, Staphylococcus spp., derived from samples of skin and ears of dogs and cats with suspected pyoderma and otitis, were isolated and analyzed. In antimicrobial susceptibility testing against Staphylococcus spp., 77\% (105/136) of the isolates were resistant to the antimicrobials tested. In the assessment of biofilm production, $83 \%(113 / 136)$ were classified as producing biofilm. In genetic characterization, $32 \%(44 / 136)$ were positive for blaZ, no isolate $(0 / 136)$ was positive for the mecA gene, and $2 \%(3 / 136)$ were positive for the icaD gene. The in vitro antimicrobial activity of the organic extract of $C$. substellata and purified usnic acid against Staphylococcus spp. ranged from $0.25 \mathrm{mg} / \mathrm{mL}$ to $0.0019 \mathrm{mg} / \mathrm{mL}$, inhibiting bacterial growth at low concentrations. The substances were more effective against biofilm-producing bacteria $(0.65 \mathrm{mg} / \mathrm{mL}-0.42 \mathrm{mg} / \mathrm{mL})$ when compared to non-biofilm producing bacteria $(2.52 \mathrm{mg} / \mathrm{mL}-2.71 \mathrm{mg} / \mathrm{mL})$. Usnic acid and the organic extract of $C$. substellata can be effective in the treatment of pyoderma and otitis in dogs and cats caused by Staphylococcus spp.
\end{abstract}

INDEX TERMS: Antimicrobial activity, Cladonia substellata, lichens, usnic acid, Staphylococcus spp., cats, dogs, bacteria, biofilm, genes.

RESUMO.- [Atividade antimicrobiana in vitro do extrato orgânico de Cladonia substellata Vainio e ácido úsnico frente Staphylococcus spp. obtidos de cães e gatos.] Cladonia substellata Vainio é um líquen encontrado em diversos continentes do mundo, inclusive no nordeste do Brasil,

\footnotetext{
${ }^{1}$ Received on March 17, 2016.

Accepted for publication on June 17, 2016.

${ }^{2}$ Laboratório de Microbiologia e Imunologia Animal, Universidade Federal do Vale do São Francisco (Univasf), Campus de Ciências Rurais, BR$407 \mathrm{Km} \mathrm{12}$, Lote 543, Projeto de Irrigação Nilo Coelho s/n, "C1", Petrolina, PE 56300-990, Brazil. Pesquisa de Mestrado com apoio CAPES. *Corresponding autor: juscikoelho@hotmail.com

${ }^{3}$ Laboratório de Bacteriologia (Labac), Centro de Ciências Rurais, De-
}

possui vários metabólitos secundários com atividade biológica, entre eles, o ácido úsnico, que tem apresentado uma vasta gama de atividades biológicas. 0 objetivo deste trabalho foi avaliar a atividade antimicrobiana in vitro do extrato orgânico de C. substellata e do ácido úsnico purificado.

partamento de Medicina Veterinária Preventiva, Universidade Federal de Santa Maria (UFSM), Av. Roraima 1000, Prédio 44, Sala 5125, Santa Maria, RS 97105-900, Brazil.

${ }^{4}$ Clínica Veterinária São Francisco (Clivesf), Rua Aureliano Francisco Neto 38, Atrás da Banca, Petrolina, PE 56308-120, Brazil.

${ }^{5}$ Departamento de Ciências Geográficas, Centro de Filosofia e Ciências Humanas, Universidade Federal de Pernambuco (UFPE), Av. Acadêmico Hélio Ramos s/n, Cidade Universitária, Recife, PE 50740-907, Brazil. 
Para isto, foram isolados Staphylococcus spp. de amostras de pele e orelha de cães e gatos com suspeita de piodermatite e otite. No teste de sensibilidade aos antimicrobianos frente Staphylococcus spp., 77\% (105/136) foram resistentes. Na avaliação da produção de biofilme 83\% (113/136) foram classificadas como produtoras de biofilme. Na caracterização genotípica, 32\% (44/136) foram positivos para o gene blaZ, nenhum isolado $(\mathrm{n}=136)$ foi positivo para o gene $m e c \mathrm{~A}$, e $2 \%(3 / 136)$ foram positivos para o gene icaD. A atividade antimicrobiana in vitro do extrato orgânico de $C$. substellata e do ácido úsnico purificado para Staphylococcus spp. variou de $0,25 \mathrm{mg} / \mathrm{ml}$ a $0,0019 \mathrm{mg} / \mathrm{ml}$, inibindo o crescimento bacteriano em baixas concentrações. Foram mais eficazes contra bactérias produtoras de biofilme $(0,65 \mathrm{mg} /$ $\mathrm{ml}-0,42 \mathrm{mg} / \mathrm{ml}$ ) quando comparadas às não produtoras de biofilme $(2,52 \mathrm{mg} / \mathrm{ml}-2,71 \mathrm{mg} / \mathrm{ml})$. Viabilizando a utilização do ácido úsnico e do extrato orgânico de C. substellata, no tratamento de otite e piodermatite em cães e gatos com o envolvimento de Staphylococcus spp.

TERMOS DE INDEXAÇÃO: Atividade antimicrobiana, Cladonia substellata, liquens, ácido úsnico, Staphylococcus spp., cães, gatos, antimicrobianos, bactérias, biofilme, genes.

\section{INTRODUCTION}

Usnic acid is a yellow substance found only in lichens (Carvalho et al. 2005) and has a strong hydrophobic nature, being derived from lichen secondary metabolites. It also provides lichen with protection against several agents that cause injuries including microorganisms, UV rays, and dryness (Cochietto et al. 2002). Furthermore, it is abundant in many phylogenetically distinct genera of lichens, such as Usnea, Cladonia, Cetraria, Parmelia, and Ramalina (Venkataramana \& Krishna 1992, Müller 2001, Cochietto et al. 2002, Ingólfsdóttir 2002, Carvalho et al. 2005). Usnic acid was first isolated in1834 from Ramalina calicaris, of Usnea barbata and other species of lichens (Rochleder \& Heldt 1996).

Usnic acid has exhibited a wide range of biological activities, such as antimicrobial, antifungal, anticancer, antiviral, antipyretic, anti-inflammatory, analgesic, and anti-protozoal activities. It also acts as an insecticide, moisturizer, antihistamine, and agent that offers protection from the harmful effects of lightning UV (Fournet et al. 1997, Cochietto et al. 2002, Ingólfsdóttir 2002, Falcão et al. 2004, Ribeiro et al. 2006, Honda et al. 2010). In humans, a hepatotoxic effect was observed when it was used systemically (Moura et al. 2008). However, it had already been in use topically for medicinal purposes, perfumery, and ecological applications in several formulations, as well as for creams, toothpaste, oral antiseptics, deodorants, and sunscreen products (Ingólfsdóttir 2002). These many possible topical applications suggest future studies to verify the use of usnic acid in animal dermatology.

Veterinary dermatology is responsible for 20 to $75 \%$ of veterinary care (Scott et al. 2001, Cardoso et al. 2011) and otological problems represent 8 to $15 \%$ of disorders in veterinary clinic in Brazil (Leite 2000). In addition, dermatopathology cases may include primary and secondary bacterial infections (Meneses et al. 2000, Cardoso et al. 2011, Muller et al. 1986) commonly associated with Staphylococccus pseudintermedius, S. aureus, and S. schleiferi (Huerta et al. 2011).

In this study, we evaluated antimicrobial susceptibility, biofilm production, and identification of BlaZ mecA and ica $\mathrm{D}$ genes in Staphylococcus spp. isolated from the skin and ears of dogs and cats with otitis and pyodermitis. In addition, we assessed the in vitro antimicrobial activity of the extract of $C$. substellata and usnic acid against all the Staphylococcus spp. isolates.

\section{MATERIALS AND METHODS}

Bacterial isolates. One hundred thirty-six isolates of Staphylococcus spp. were obtained from pyoderma and otitis in dogs and cats in the Brazilian states of Pernambuco (PE) and Rio Grande do Sul (RS) from 1990 to 2012 (Table 1).

From a total of 136 isolates of Staphylococcus spp., 110 were obtained in Petrolina, PE, from private clinics and the veterinary hospital at Univasf in 2011 to 2012. The samples were collected with sterile swabs, kept in a modified Stuart medium under refri-

Table 1. Characteristics of isolates of Staphylococcus spp. $(\mathrm{n}=136)$ of dogs and cats

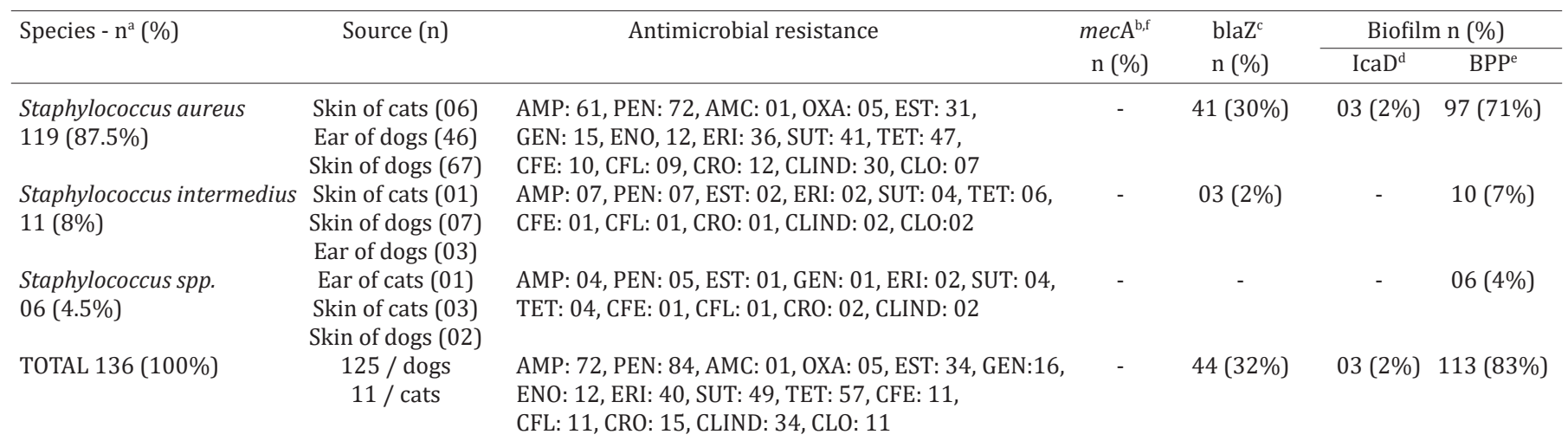

a Total number of each isolate, ${ }^{\mathrm{b}, \mathrm{c}}$ genes related to the bacterial virulence factor, ${ }^{\mathrm{d}}$ gene associated with bacterial biofilm production, ${ }^{\mathrm{e}}$ quantitative technique to assess biofilm production in microplates, ${ }^{\mathrm{f}}$ Not detected/absent- AMP $(10 \mu \mathrm{g})$ ampicillin, PEN $(10 \mu \mathrm{g})$ penicillin, AMC $(30 \mu \mathrm{g})$ amoxicillin+clavulanic acid, OXA $(1 \mu \mathrm{g})$ oxacillin, EST $(10 \mu \mathrm{g})$ streptomycin, GEN $(10 \mu \mathrm{g})$ gentamicin, ENO $(5 \mu \mathrm{g})$ enrofloxacin, ERI $(15 \mu \mathrm{g})$ eritromicin, SUT $(25 \mu \mathrm{g})$ Sulfamethoxazole, TET $(30 \mu \mathrm{g})$ tetracycline, CFE $(30 \mu \mathrm{g})$ cephalexin, CFL $(30 \mu \mathrm{g})$ cephalothin, CRO $(30 \mu \mathrm{g})$ ceftriaxone, CLIND $(2 \mu \mathrm{g})$ clindamycin, CLO $(30 \mu \mathrm{g})$ chloramphenicol. 
geration, and sent within 24 hours after collection to the Animal Microbiology and Immunology Laboratory at Univasf (Petrolina/ PE). The other 26 isolates were provided by the Laboratory of Bacteriology (Labac) of the Department of Preventive Veterinary Medicine, Universidade Federal de Santa Maria (UFSM); these samples were collected from the years 1990 to 1995 in three different municipalities in southern Brazil, as Santa Maria (RS), Santa Cruz do Sul (RS), and Caçapava do Sul (RS). The isolates were first identified, freeze dried, and refrigerated at Labac, and then sent chilled to the Animal Microbiology and Immunology Laboratory at Univasf in 2011.

Source of the lichen Cladonia substellata and usnic acid. The lichen C. substellata, source of the organic extract and usnic acid, was collected on sandy soils of the coastal tablelands of Mamanguape of Paraíba, which corresponds to the northeastern Coastal Plains area. It was identified through the morphological and chemical characteristics of its stem. Subsequently, organic extracts and purified usnic acid were obtained in the Laboratório de Produtos Naturais (Natural Products Laboratory) at UFPE (Universidade Federal de Pernambuco).

Preparation of organic extract of $\boldsymbol{C}$. substellata and isolation of usnic acid. Organic extracts were obtained by an exhaust system at room temperature $\left(28 \pm 3^{\circ} \mathrm{C}\right)$ from dry lichen thallus $(20 \mathrm{~g})$ following the ether, chloroform, and acetone series. The material was ground in a mortar and extracted with $100 \mathrm{~mL}$ of ethyl ether under stirring for $1 \mathrm{~h}$, and then maintained at $6^{\circ} \mathrm{C}$ for $24 \mathrm{~h}$. After this period, the material was filtered and the residue extracted with the same volume of chloroform. Then, after filtration, the residue was extracted again with acetone under the same conditions. The extracts were then evaporated at room temperature and kept in a desiccator until constant weight (Nóbrega et al. 2012). The usnic acid was isolated and purified by the method of recrystallization from diethyl ether extract (Pereira 1998) in the Natural Products Laboratory of the UFPE.

Thin Layer Chromatography (TLC). The ethereal extract, chloroform, and acetone were subjected to ascending chromatography on silica gel plates $60 \mathrm{~F} 254+366$ (Merck), $20 \times 20 \mathrm{~cm}$, and were developed in the solvent systems A (toluene/dioxane/acetic acid system 180: 45: 5v/v) and B (hexane/diethyl ether/formic acid 130: 80: 20v/v) (Culberson, 1972). The bands obtained were visualized under UV light at $254 \mathrm{~nm}$ and $366 \mathrm{~nm}$. The chromatoplates were then stained with $10 \% \mathrm{H}_{2} \mathrm{SO}_{4}$ and heated at $100^{\circ} \mathrm{C}$ for $10 \mathrm{~min}$. The highlighted bands were compared by staining reaction and values of Rf (Retention Factor), with patterns of usnic acid applied as standards.

\section{Bacterial identification}

Morphological and biochemical identification. Bacterial isolates from samples of pyoderma and otitis in dogs and cats were kept in the Animal Microbiology and Immunology Laboratory of Univasf in Petrolina/PE, Brazil. The samples were smeared on $5 \%$ blood agar using a platinum loop and incubated at $37^{\circ} \mathrm{C}$, and the plates were read at $24 \mathrm{~h}$ and $48 \mathrm{~h}$. Bacterial agents were identified by colonial, biochemical, and morphological characteristics (Mannitol semi-solid, semi-solid glucose, maltose Purple Agar Base, urease, catalase, oxidase, coagulase with DNase and rabbit plasma in a tube), and stained (Gram Stain) (Quinn et al. 2005). Coagulase enzyme production divided staphylococci into two groups: coagulase-positive and coagulase-negative (Ziebuhr et al. 2006).

Molecular identification. Total bacterial DNA was extracted and purified following the protocols described by Wade et al. (2005) and Ausubel et al. (1987) with modifications. An inoculum of each strain was placed in $300 \mu \mathrm{L}$ of TE (Tris-EDTA) and heat inactivated $\left(80^{\circ} \mathrm{C} / 10 \mathrm{~min}\right)$ in dry bath. After that, we added $70 \mu \mathrm{L}$ of $10 \%$ SDS, with subsequent addition of $100 \mu \mathrm{L}$ of $5 \mathrm{M} \mathrm{NaCl}_{2}$ and $80 \mu \mathrm{L} \mathrm{CTAB} / \mathrm{NaCl}$. This solution was incubated at $65^{\circ} \mathrm{C}$ for $10 \mathrm{~min}$. Then, $700 \mu \mathrm{L}$ of chloroform/isoamyl alcohol (24:1) was added, homogenized by inversion, and centrifuged at 11,750g for $5 \mathrm{~min}$. Subsequently, the liquid from the 1st stage was transferred to another clear tube and $450 \mu \mathrm{l}$ of isopropanol was added. The tube was kept on ice for $20 \mathrm{~min}$ and centrifuged at 11,750g for $15 \mathrm{~min}$, discarding the supernatant and adding $500 \mu \mathrm{L}$ of $70 \%$ ethanol, spun at $11,750 \mathrm{~g}$ for $10 \mathrm{~min}$. The supernatant was discarded and the pellet was dried at room temperature. It was then resuspended in $80 \mu \mathrm{L}$ of TE $(\mathrm{pH} 8.0)$ and incubated at $65^{\circ} \mathrm{C}$ for $1 \mathrm{~min}$. Total DNA was stored at $-20^{\circ} \mathrm{C}$.

Staphilococcus aureus molecular characterization was performed by identifying a fragment of the nuc gene $(279 \mathrm{pb})$ with the primers F-GCGATTGATGGTGATACGGTT 5'-3' and 5'-R-AGCCAAGCCTTGACGAACTAAAGC-3' (Kateete et al. 2010). The non-quantified DNA template $(4 \mu \mathrm{L})$ extracted from bacterial strains was added to $11 \mu \mathrm{L}$ of mix containing $0.66 \mu \mathrm{M}$ of each primer, $0.4 \mathrm{mM}$ dNTPs, $1 \mathrm{X}$ diluted enzyme buffer, $2 \mathrm{mM} \mathrm{MgCl} 2$, and 1.5U Taq DNA polymerase. Amplifications were performed in a thermocycler (AMPLITHERM TX96 Plus + G) with an initial denaturation at $94^{\circ} \mathrm{C}$ for $5 \mathrm{~min}$, followed by 37 cycles, each consisting of $94^{\circ} \mathrm{C}$ for $1 \mathrm{~min}$, primer annealing at $55^{\circ} \mathrm{C}$ for $30 \mathrm{~s}$ and extension at $72^{\circ} \mathrm{C}$ for $1 \mathrm{~min}$, followed by a final extension at $72^{\circ} \mathrm{C}$ for 7 min (adapted from Kateete et al. 2010). S. epidermidis was identified by a fragment of $130 \mathrm{pb}$ of rdr gene with the primers SERF-5'AAGAGCGTGGAGAAAAGTATCAAG3' and SERR-5'TCGATACCATCAAAAAGTTGG3' (Shome et al. 2011). The non-quantified DNA template $(5 \mu \mathrm{L})$ extracted from bacterial strains was added to $20 \mu \mathrm{L}$ of mix containing $0.5 \mu \mathrm{M}$ primer, $0.4 \mathrm{mM} \mathrm{dN}$ TPs, $1 \mathrm{X}$ diluted enzyme buffer, $1.5 \mathrm{mM} \mathrm{MgCl}_{2}$, and $2.5 \mathrm{U}$ Taq DNA polymerase. Amplifications were performed in a thermocycler (AMPLITHERM TX96 Plus $+G$ ) with an initial denaturation at $94^{\circ} \mathrm{C}$ for $5 \mathrm{~min}$, followed by 30 cycles, each consisting of denaturation at $94^{\circ} \mathrm{C}$ for $30 \mathrm{~s}$, primer annealing at $60{ }^{\circ} \mathrm{C}$ for $30 \mathrm{~s}$ and extension at $72^{\circ} \mathrm{C}$ for $45 \mathrm{~s}$, followed by a final extension at $72^{\circ} \mathrm{C}$ for $10 \mathrm{~min}$ (adapted from Shome et al. 2011). The PCR products $(5 \mu \mathrm{L})$ were verified in $1.5 \%$ agarose gel, stained with ethidium bromide, and documented by the Kodak Digital Science 1D Capture imaging system. The controls used were S. aureus ATCC 25923 (nuc) and S. epidermids ATCC 12228 (rdr) (positive control DNA) and nuclease-free water (negative control).

\section{Antimicrobial susceptibility testing}

Phenotypic test. The sensitivity profile of the microorganisms was determined by the modified Kirby-Bauer disk diffusion method (Bauer et al. 1996). The isolates were seeded into Müller-Hinton broth and incubated at $37^{\circ} \mathrm{C}$ to obtain a turbidity of 0.5 McFarland scale. The isolates were smeared on Petri dishes containing Müller-Hinton agar. The disks were then impregnated with the following groups/antimicrobial drugs: i) beta-lactams:

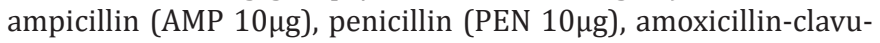

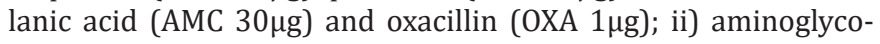

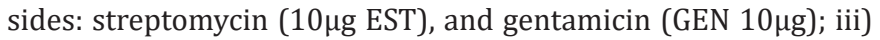
quinolones: enrofloxacin (ENO $5 \mu \mathrm{g}$ ); iv) Macrolides: erythromy-

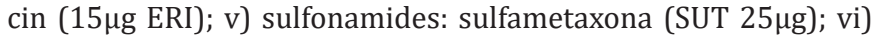
tetracyclines: tetracycline $(30 \mu \mathrm{g}$ TET); vii) cephalexin: cephalexin

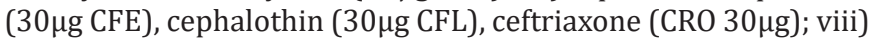
lincosamides: clindamycin (CLIND $2 \mu \mathrm{g}$ ); and ix) amphenicols:

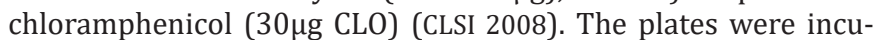
bated at $37^{\circ} \mathrm{C}$ for $24 \mathrm{~h}$. The halos were then measured and the sensitivity profile of the isolates was determined following the classifications of sensitive, intermediate, and resistant, according to the document M31-A3 (CLSI, 2008). The Multiple Antibiotic Resistance Index (MARI) was calculated according to the methodol- 
ogy described by Schwarz et al. (2010). This index is determined by the ratio between the number of antimicrobials that the sample was resistant to and the total number of drugs from the group of $\beta$-lactams tested.

Genotypic test. Molecular confirmation of the presence of genes linked to resistance to the $\beta$-lactam group was assessed by amplification of mecA and blaZ gene fragments. The primers used for amplification of $217 \mathrm{pb}$ of the mecA gene were F-5'AAAATCGATGGTAAAGGTTGGC3' and R-5'AGTTCTGCAGTACCGGATTTGC3' (Coelho et al. 2007); and for amplification of $517 \mathrm{pb}$ of the blaZ gene were F-5'AAGAGATTTGCCTATGCTTC3' and R-5'GCTTGACCACTTTTATCAGC3' (Sawant et al. 2009). The PCR reaction of the mecA gene was DNA template ( 100-200ng), $0.4 \mu \mathrm{M}$ of each primer, $0.4 \mathrm{mM}$ of dNTP, $1 \mathrm{X}$ enzyme buffer, $2 \mathrm{mM} \mathrm{MgCl}_{2}$, and $1.5 \mathrm{U}$ Taq in a final volume of $15 \mu \mathrm{L}$. This reaction was placed in a thermocycler (AMPLITHERM TX96 Plus + G) and subjected to initial denaturation at $94^{\circ} \mathrm{C}$ for $1 \mathrm{~min}$, followed by 15 cycles at $94^{\circ} \mathrm{C}$ for $30 \mathrm{~s}, 68^{\circ} \mathrm{C}$ for $30 \mathrm{~s}$, and $72^{\circ} \mathrm{C}$ for $30 \mathrm{~s}$, followed by 20 cycles at $94^{\circ} \mathrm{C}$ for $30 \mathrm{~s}, 60^{\circ} \mathrm{C}$ for $30 \mathrm{~s}, 72^{\circ} \mathrm{C}$ for $30 \mathrm{~s}$, and a final extension at $72^{\circ} \mathrm{C}$ for 2 min (adapted from Coelho et al. 2007). The PCR for the blaZ gene was the same used for the mecA gene. However, the thermal conditions were initial denaturation at $94^{\circ} \mathrm{C}$ for $4 \mathrm{~min}$, followed by 30 cycles at $94^{\circ} \mathrm{C}$ for $1 \mathrm{~min}, 50.5^{\circ} \mathrm{C}$ for $30 \mathrm{~s}, 72^{\circ} \mathrm{C}$ for $30 \mathrm{~s}$, and a final extension at $72^{\circ} \mathrm{C}$ for $5 \mathrm{~min}$ (Sawant et al. 2009).

The PCR products were analyzed in $1.5 \%$ agarose gel, stained with ethidium bromide, and documented by the image capturing system (Kodak 1D Digital Science) (adapted from Coelho et al. 2007, Sawant et al. 2009).

Characterization of biofilm production in Staphylococcus spp.

Phenotypic characterization. Quantitative analysis of Staphylococcus spp. biofilm formation $(\mathrm{n}=136)$ in the 96-well polystyrene microplates was performed according to Merino et al. (2009) with modifications. In the phenotypic characterization of biofilm formation, Staphylococcus spp. isolates were previously identified and chilled. The bacteria were seeded into Tryptic Soy Agar (TSA) and incubated at $37^{\circ} \mathrm{C}$ for $24 \mathrm{~h}$. Single colonies were inoculated in $3 \mathrm{~mL}$ of Trypticase Soy Broth (TSB) until a turbidity of $0.5 \mathrm{McF}$ arland, and incubated at $37^{\circ} \mathrm{C}$ for $24 \mathrm{~h}$. Then, $5 \mu \mathrm{l}$ were transferred to microdilution plates containing TSB $(195 \mu \mathrm{L})$ and incubated at $37^{\circ} \mathrm{C}$ for $24 \mathrm{~h}$. They were rinsed three times with $200 \mu \mathrm{L}$ of distilled water and dried at room temperature (RT). The plates were then stained with $0.25 \%$ violet crystal $(100 \mu \mathrm{L})$ for 3 min at RT. After that, the plates were rinsed three times with distilled water. To dissolve the dye, an alcohol-acetone $(80: 20)$ solution $(200 \mu \mathrm{L})$ was used. Absorbance was measured in an ELISA plate reader using a $620 \mathrm{~nm}$ filter. All analyses were performed in triplicate, using positive and negative controls. S. aureus (ATCC 25923), previously characterized genotypically for biofilm production, was used for positive control. After reading, the samples were classified into four categories: non-adherent $(0)$ when the OD (Optical Density) obtained is less than the OD of the negative control (ODc); weakly adherent (+):ODc $<0 D \leq 2 x$ ODc; moderately adherent $(++)$ : $2 x$ ODc $<0 D \leq 4 x$ Doc; and strongly adherent $(++$ + ): 4xODc $\leq$ OD (adapted from Merino et al. 2003). All assays were performed three times.

Genotypic characterization. To amplify the IcaD gene, we used the primers ICADF (5'AAA AAG AGA CGT GGT GG3 ') and ICADR (5'GGC ATC ATG AAT ATA AAG C3'), which amplified a fragment of 381pb (Vasudevan et al. 2003). The PCR reaction consisted of $1.33 \mathrm{mM} \mathrm{MgCl}_{2}, 0.2 \mathrm{mM} \mathrm{dNTP}, 1 \mu \mathrm{M}$ of each primer, $1.5 \mathrm{U}$ Taq polymerase, and $2 \mu \mathrm{L}$ of DNA template ( 100ng) ("bacterial and molecular identification") in a final volume of $15 \mu \mathrm{L}$. This reaction was placed in a thermocycler (AMPLITHERM TX96 Plus + G) and the thermal conditions were: initial denaturation at $94^{\circ} \mathrm{C}$ for
$2 \mathrm{~min}$, followed by 30 cycles at $94^{\circ} \mathrm{C}$ for $2 \mathrm{~min}$, at $92^{\circ} \mathrm{C}$ for $45 \mathrm{~s}$, and at $72^{\circ} \mathrm{C}$ for $1 \mathrm{~min}$, with a final extension at $72^{\circ} \mathrm{C}$ for $7 \mathrm{~min}$. The PCR products were analyzed in $1.5 \%$ agarose gel, stained with ethidium bromide, and documented by the image capturing system (Kodak 1D Digital Science) (adapted from Vasudevan et al. 2003). S. aureus ATCC 25923 was used as a positive control and nuclease-free water as a negative control.

Determination of the antibacterial activity of the organic extract of $C$. substellata and usnic acid against Staphylococcus spp. To determinate the in vitro antibacterial activity of the organic extract of $C$. substellata and purified usnic acid against 136 Staphylococcus spp. isolates, the Minimum Inhibitory Concentration (MIC) and Minimum Bactericidal Concentration (MBC) were established based on the CLSI document, using the following concentrations: $0.25 \mathrm{mg} / \mathrm{mL}, 0.125 \mathrm{mg} / \mathrm{mL}, 0.0625 \mathrm{mg} / \mathrm{mL}$, $0.0312 \mathrm{mg} / \mathrm{mL}, \quad 0.0156 \mathrm{mg} / \mathrm{mL}, \quad 0.0078 \mathrm{mg} / \mathrm{mL}, \quad 0.0039 \mathrm{mg} / \mathrm{mL}$, and $0.0019 \mathrm{mg} / \mathrm{mL}$, in triplicate, in accordance with the document M100-S20 (CLSI 2010).

An inoculum of a bacterial suspension was prepared in Mueller-Hinton agar with turbidity equivalent to 0.5 on the McFarland scale. The lichen extracts were diluted to a concentration of $0.50 \mathrm{mg} / \mathrm{mL}$ in $200 \mu \mathrm{L}(1: 2)$ of Mueller-Hinton Broth (MH). This suspension was inoculated $(10 \mu \mathrm{L})\left(1 \times 10^{4} \mathrm{UFC} / \mathrm{mL}\right)$ in each well containing a dilution of each extract. The plates were incubated at $37^{\circ} \mathrm{C}$ for $24 \mathrm{~h}$ under aerobic conditions and the sequence was determined; with $\mathrm{MIC}_{50}$ and $\mathrm{MIC}_{100}$ being considered as partial and complete visual inhibition of bacterial growth. For the dilutions where no visible bacterial growth was observed, an aliquot $(10 \mu \mathrm{L})$ was removed and seeded on Mueller-Hinton agar (MH agar). The material was incubated at $37^{\circ} \mathrm{C}$ for $24 \mathrm{~h}$. The MBC was determined as the lowest concentration of the extract under study capable of causing the death of the microorganism tested. All assays were performed in triplicate.

Interaction of the organic extract of $C$. substellata and purified usnic acid with the consolidated bacterial biofilm. Nineteen isolates of Staphylococcus spp. previously identified as biofilm producers were evaluated in this study. Biofilm formation in microplates was obtained from incubation of the bacterial suspension (inoculum) $(100 \mu \mathrm{l})$ in each well of the 96 -well plate. The plates were incubated at $37^{\circ} \mathrm{C}$ for $24 \mathrm{~h}$. After that, the wells were rinsed three times with distilled water. Then, $100 \mu$ l of the organic extract of $C$. substellata and purified usnic acid at a concentration of $0.25 \mathrm{mg} / \mathrm{mL}$ were added. This concentration was capable of inhibiting bacterial growth of all 136 Staphylococcus spp. tested $\left(\mathrm{MIC}_{100}\right.$ and $\mathrm{MBC}_{100}$ ). The optical density (OD) was determined immediately after addition of the extract $(0 \mathrm{~h})$ and after $24 \mathrm{~h}$. Interference in the consolidated biofilm was defined by the equation: $\mathrm{OD}_{0 \mathrm{~h}}$ mean $/ \mathrm{OD}_{24 \mathrm{~h}}$ mean x 100 (Adapted from Nostro et al. 2007). All assays were performed in triplicate.

Interaction of the organic extract of $C$. substellata and purified usnic acid with bacterial biofilm formation. A concentration of $0.25 \mathrm{mg} / \mathrm{mL}$ of organic extract of C. substellata and purified usnic acid (concentration able to inhibit the bacterial growth of 136 Staphylococcus spp. tested at $\mathrm{MIC}_{100}$ and $\mathrm{MBC}_{100}$ ) was used on the biofilm in formation. This assay was performed in 96 -well microplates. Bacterial inoculum were cultured in $10 \mathrm{~mL}$ of TSB with $1 \%$ of glucose at $1 \%$ and kept at $37^{\circ} \mathrm{C}$ for $24 \mathrm{~h}$. A quantity of $100 \mu \mathrm{l}$ was added to the wells of the plate, to which $100 \mu$ l of extract and $100 \mu \mathrm{l}$ of culture medium in the controls had previously been added. After $24 \mathrm{~h}$ of incubation at $37^{\circ} \mathrm{C}$, the plates were stained with crystal violet. The effectiveness of the extract in interfering with biofilm formation was defined by the equation: mean OD of treated well/ mean OD of control wells x 100 (adapted from Nostro et al. 2007). Nineteen samples of biofilm-producing Staphylococcus spp. (which were collected from pyodermatitis in dogs (16) and 
cats (03) in 2011-2013 in Petrolina, PE, Brazil) were evaluated in regard to interaction of the consolidated biofilm against organic extract of $C$. substellata and purified usnic acid at a concentration of $0.25 \mathrm{mg} / \mathrm{mL}$. All assays were performed in triplicate.

Statistical analyses. Statistical analysis was performed using the Fisher exact test for analysis of correlation between biofilm production and the presence of the icaD gene, as well as the relationship between the presence or absence of the blaZ gene for resistance or susceptibility to $\beta$-lactam antibiotics (ampicillin, penicillin, amoxicillin+clavulanic acid, and oxacillin) (Reis 1998). The Wilcoxon test was used to verify differences between ordered pairs for comparison of the antimicrobial effect of the organic extract of $C$. substelatta and purified usnic acid (Sampaio 2007). All analyses were performed using the R statistical software (R Core Team 2012).

\section{RESULTS AND DISCUSSION}

\section{Bacterial identification}

One hundred and thirty-six isolates of Staphylococcus spp. (Table 2) were classified as Gram-positive, catalasepositive and oxidase-negative. From these, 116 were classified as coagulase-positive and 20 were coagulase-negative. Through biochemical tests, it was possible to identify $70 \mathrm{~S}$. aureus, 11 S. intermedius, 46 Staphylococcus spp. coagulasepositive and 20 Staphylococcus spp. coagulase-negative isolates. To identify $S$. aureus and S. epidermids, nuc and $r d r$ genes, respectively, were evaluated by PCR. One hundred and nineteen isolates were positive for the nuc gene $(S$. aureus), in the absence of amplification of the $r d r$ gene ( $S$. epidermidis); five isolates were classified as Staphylococcus coagulase-positive, and one as Staphylococcus coagulasenegative.

From the 119 S. aureus isolates, 18 were coagulase-negative and six DNase-negative by biochemical testing. PCR showed greater sensitivity and specificity in the identification of $S$. aureus by nuc gene amplification as compared to biochemical testing. Furthermore, 15\% (18/119) were negative in the coagulase test, similar to the findings of Koneman et al. 1997. It should be noted that rare strains of $S$. aureus might be coagulase-negative. In addition, 5\% $(6 / 119)$ of the isolates were negative by the DNase test, which was also reported by Rao et al. (2002) and Kateete et al. (2010). Other biochemical tests included mannitol semi-solid medium, semi-solid glucose medium, maltose plus purple agar base, urease, catalase, and oxidase. There was no difference in identification of $S$. aureus through biochemical results as compared to PCR.

The isolates from pyodermatitis and otitis of dogs and cats were predominantely $S$. aureus $87.5 \%(119 / 136)$ and $S$. intermedius 8\% (11/136). According to Frank et al. (2003), $S$. aureus is more prevalent in humans, while $S$. intermedius

Table 2. Interaction of organic extract (Cladonia substellata Vainio) and purified usnic acid with biofilm (Staphylococcus spp.)

\begin{tabular}{|c|c|c|}
\hline Extract/Fraction ${ }^{\mathrm{a}}$ & $\begin{array}{l}\text { Inhibition of biofilm } \\
\text { in formation - \% (n) }\end{array}$ & $\begin{array}{c}\text { Inhibition of consolidated } \\
\text { biofilm - \% (n) }\end{array}$ \\
\hline Organic extract & $42(8 / 19)$ & $47(9 / 19)$ \\
\hline Usnic acid & $37(7 / 19)$ & $58(11 / 19)$ \\
\hline
\end{tabular}

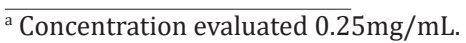

and S. schleiferi are more prevalent in dogs. In this study, among the 50 isolates of otitis ( $49 \mathrm{dogs}$ ), $6 \%$ were identified as $S$. intermedius and $94 \%$ were S. aureus. The results obtainded in this study also disagree with results from Cole et al. (1998) and Lilenbaum et al. (2000), which showed that $S$. intermedius was the main bacterial agent isolated from otopathologies in dogs. The possible occurrence of a zoonotic transmission of Staphylococcus spp. strains from pets to humans has already been described in the literature (Tanner et al. 2000, Cizman 2003, Kikuchi \& Ohshima 2004, Oliveira et al. 2005). However, a possible bacterial inverse migration from man to animal could explain the high occurrence of $S$. aureus in skin and otologic diseases described in this study.

\section{Antimicrobial susceptibility tests}

Phenotypic test. Nine classes of antimicrobials were tested: $\beta$-lactams, aminoglycosides, quinolones, macrolides, sulfonamides, tetracyclines, cephalexin, lincosamides, and amphenicols. Thirty-two percent of the isolates (44/136) were resistant to more than four classes of antimicrobials, $10 \%(13 / 136)$ to three classes, $16 \%(22 / 136)$ to two classes, $19 \%(26 / 136)$ to only one class, and $23 \%$ $(31 / 136)$ showed no resistance to any antimicrobial tested.

From the 136 isolates, 70 were resistant to more than two antimicrobial groups of $\beta$-lactam antibiotics (ampicillin, penicillin, amoxicillin+ clavulanic acid, and oxacillin) (Multiple Antibiotic Resistance Index, MARI $\geq 0.5$ ), 13 isolates showed resistance only to penicillin, two isolates were resistant to ampicillin, and 51 isolates showed no resistance to any antimicrobial tested in vitro. The highest resistance of the isolates was observed against $\beta$-lactams; the sensitivity of the isolates to these drugs was verified in $37 \%$ (50/136) of the bacteria. Within this group, amoxicillin associated with clavulanate potassium and oxacillin showed efficiency exceeding 96\%. In contrast, the antimicrobial groups with greatest activity against Staphylococcus spp. were amphenicols, quinolones, and cephalexin, to which the isolates exhibited sensitivity greater than or equal to 80\% (109/136). Meng \& Doyle (1998) cited in their study that drug resistance may be related to the excessive and oftentimes irresponsible use of antibiotics. This fact could explain the high resistance to the $\beta$-lactam antibiotics, which have been used in veterinary medicine, especially for treatment of diseases involving respiratory, orthopedic, urinary, respiratory, and dermatological systems.

Low resistance against quinolones was also described in previous studies (Junco \& Barrasa 2002, Hoekstra \& Paulton 2002). Junco \& Barrasa (2002) warned that indiscriminate use of fluoroquinolones and, in particular, enrofloxacin, could result in an increase in bacterial resistance. Concerning the cephalosporin group, other authors reported over $90 \%$ susceptibility of Staphylococcus spp. isolated from pets (Bornand 1992, Cole et al. 1998, Oliveira et al. 2006, Santos 2007). Over $80 \%$ susceptibility of Staphylococcus spp. to chloramphenicol is reported by Oliveira et al. (2000) and Batista et al. (1998). However, Vandžurová et al. (2013) described strains of S. nepalensis resistant to chloramphenicol. 


\section{Antimicrobial susceptibility tests}

Genotypic test. From the 136 isolates of Staphylococcus spp. assessed by PCR, 32\% (44/136) were positive for the blaZ gene. Forty were identified as $S$. aureus, three as $S$. intermedius, and only one as coagulase positive Staphylococcus. All were negative in amplification of the mecA gene. The Fisher exact test did not identify any relationship $0 \%$ $(0 / 136)$ between the presence of the blaZ gene and in vitro resistance to the beta-lactam group of antibiotics (Reis 1998).

In those isolates that were positive for the blaz gene, there may be the presence of a bacterial resistance mechanism to produce $\beta$-lactamases, enzymes that hydrolytically destroy $\beta$-lactam compounds (Fuda et al. 2005) on the sites where $\beta$-lactam antimicrobials bind to bacterial PBPs (Penicillin Binding Protein), exercising the antimicrobial effect (Oliveira 2011). In this study, using PCR, it was possible to identify a large number of Staphylococcus spp. resistant to $\beta$-lactam antimicrobials through the presence of the blaZ gene. These values are higher than those found by Schlotter et al. (2013). The authors detected $11.1 \%$ (21 samples isolated from bovine milk) of Staphylococcus spp. that were penicillin-resistant in vitro and positive for the blaz gene in a PCR assay. Livorsi et al. (2012) isolated $77 \%$ of $S$. aureus (human bloodstream) resistant to the $\beta$-lactam group, although susceptible to methicillin (Methicillin-Sensitive Staphylococcus aureus - MSSA), and which had the blaZ gene, confirmed by the PCR technique in the S. aureus isolates.

From the isolates positive for the blaz gene, 12 were sensitive to $\beta$-lactam antibiotics in vitro and 32 samples were multiresistant (penicillin and ampicillin). From these, one sample of $S$. aureus was also resistant to amoxicillin associated with potassium clavulanate. In this case, clavulanic acid irreversibly binds to $\beta$-lactamases and inhibits their effect (Oliveira 2011). This raises the possibility that other factors may be involved in resistance in addition to the presence of the blaZ gene and production of $\beta$-lactamases. The presence of the mecA gene was also negative in this sample, reinforcing the possibility of involvement of one or more other resistance genes, outside the mecA gene, as well as the possibility of other resistance mechanisms.

One of the multidrug-resistant $S$. aureus isolates (positive for the blaZ gene) was resistant to oxacillin in vitro, and negative for the mecA gene. However Aarestrup et al. (2001) describe the modification of PBPs, synthesized by the mecA gene, as one of the major mechanisms of resistance described against oxacillin, there are other genes that were not evaluated in this study and that may be responsible for this resistance. Such genes include the presence of the chromosomal cassette SCCmec (Hiramatsu 1995), responsible for the transport of mecA genes (Katayama et al. 2000), the presence of mecI-mecR1 genes, responsible for transcriptional control of mecA (Oliveira 2011), and other genes and/or resistance mechanisms.

From the 136 isolates, five (4\%) were resistant to oxacillin in vitro, three isolates of $S$. aureus, and a coagulase positive and a coagulase negative sample; however, no sample was positive for the mecA gene. Only one of them was positive for the bla $\mathrm{Z}$ gene and showed resistance to all groups of antimicrobials tested. Bemis et al. (2006) compared some tests to determine resistance to oxacillin and detection of the mecA gene. As result, PCR and disk diffusion tests were satisfactory for determining resistance in $S$. aureus isolates from canine hosts. Oliveira (2011) stated that MRSA (Methicillin-Resistant Staphylococcus aureus) is inherently cross-resistant to virtually all $\beta$-lactam antimicrobials. In this study, none of the samples showed that the resistance was positive for the mecA gene, suggesting the presence of other resistance mechanisms, possibly associated with BORSA (Borderline Oxacilin-Resistant Staphylococcus aureus) which may occurr due to overproduction of beta-lactamases (Perillo et al. 2012). This could explain the resistance to amoxicillin associated with clavulanate potassium exhibited by one of the strains of $S$. aureus.

The isolates that were resistant to oxacillin were also negative for the mecA gene, and they may be meticillinase producers since they were inhibited by clavulanic acid or have other resistance factors, such as the presence of PBPs (penicillin binding proteins) mutants (Borderline Resistant Staphylococcus aureus - Borsa), among other resistance mechanisms linked to oxacillin. Previous reports showed the prevalence of $42 \%$ (Coelho et al. 2007), 57.6\% (Duijkeren et al. 2004), and 99\% (Grisold et al. 2002) of the mecA gene in Staphylococcus spp. multidrug resistance in vitro to oxacillin. For Schlotter et al. (2013), only four isolates $(2.1 \%)$ showed the presence of the mecA gene, although they exhibited in vitro oxacillin resistance. Frey et al. (2013) reported $9.7 \%$ of isolates as oxacillin resistant, and this resistance was attributed to the presence of the $m e c$ A gene, whereas it was also detected in S. fleurettii, $S$. epidermidis, S. haemolyticus, and S. xylosus. Furthermore, penicillin-resistance was attributed to the presence of the blaZ gene. In Japan, Kawakami et al. (2010) reported the mecA gene in $66.5 \%(113 / 170)$ of $S$. pseudintermedius and $30.0 \%(6 / 20)$ of $S$. schleiferi isolated from canine pyoderma, suggesting a high degree of resistance to methicillin. In Italy, Ghidini et al. (2011) isolated Staphylococcus spp. from skin lesions in dogs - 28 staphylococci strains were methicillin and/or oxacillin resistant, with confirmation of the mecA gene in 14 samples. Further studies are required involving unidentified factors and additional determinants reputedly controlling transcription of the mecA gene, as well as the mecA regulatory mechanism in contemporary MRSA, as suggested by Oliveira (2011).

\section{Characterization of biofilm production by Staphylococ- cus spp. \\ Phenotypic characterization. Among the 136 isolates} evaluated for biofilm production by the quantitative technique of biofilm formation in microplates, 57\% (78/136) were classified as strongly adherent, $10 \%(13 / 136)$ as moderately adherent, $16 \%(22 / 136)$ as weakly adherent, and $17 \%(23 / 136)$ as non-adherent. Biofilm formation provides for bacterial protection against dehydration and colonization by bacteriophages. It also promotes antimicrobial resistance and avoids phagocytosis (Gilbert et al. 2003, Zhao et al. 2008). In this study, $83 \%$ of the isolates were biofilm producers and this feature may be one im- 
portant mechanism of resistance that prevents the action of antimicrobial drugs routinely used in control of microorganisms. Yeon-Soo et al. (2008) highlighted the public health significance of involvement of biofilm-producing Staphylococcus spp. isolated from the skin and ears of dogs and cats in direct contact with humans.

\section{Characterization of biofilm production by Staphylococ- cus spp.}

Genotypic characterization. One hundred thirty-six isolates of Staphylococcus spp. were analyzed for the presence of the icaD gene (Table 2), which may be related to the production of biofilm. Three $(2 \%)$ isolates were positive for the icaD gene - one isolate was classified as weakly adherent and the other two as strongly adherent by the quantitative technique of biofilm formation in microplates (phenotypical test).

The Fisher exact test did identify any correlation between the presence of the icaD gene and the production of biofilm by Staphylococcus spp. (Reis 2003). Arciola et al. (2001) found the presence of the icaD gene in $61 \%$ of 23 strains of $S$. aureus isolated from humans, a rate higher than the results from this study. Eftekhar \& Speert (2009) reported that icaADBC operon, which is included in the ica $\mathrm{D}$ gene, cannot be used as the only indication of the biofilm phenotype since the conditions for bacterial growth play an important role in this formation, or there may be biofilm formation by other mechanisms (e.g. exopolysaccharide intercellular adhesion, PIA) that are not associated with the icaD gene expression. This could help explain our findings, since $83 \%$ of bacteria were identified as biofilm producing by the phenotypic test and only $2 \%$ were positive for the presence of the icaD gene.

\section{Determination of antibacterial activity of organic ex-} tract of $C$. substellata and purified usnic acid

The concentration of $0.0019 \mathrm{mg} / \mathrm{mL}$ for both the organic extract of $C$. substellata and purified usnic acid was able to inhibit the growth of most strains of Staphylococcus spp. (Fig.1). The Minimum Inhibitory Concentration (MIC) and Minimum Bactericidal Concentration (MBC) for all 136 isolates ranged from $0.25 \mathrm{mg} / \mathrm{mL}-0.0019 \mathrm{mg} / \mathrm{mL}$, with an average of $0.0796 \mathrm{mg} / \mathrm{mL}$ for both the organic extract of $C$. substellata and purified usnic acid, and antimicrobial activity was $100 \%$ for all 136 isolates.

There was no significant difference in comparison of the antibacterial effect of the organic extract of $C$. substellata and purified usnic acid against Staphylococcus spp. when using the Wilcoxon test (Sampaio 2007). This can be explained by the composition of the organic extract of $C$. substellata originating from the Northeast of Brazil, with approximately $98 \%$ usnic acid in its composition (Huovinen \& Ahti 1986, Ahti et al. 1993, Yano-Melo et al. 1999). This may be primarily responsible for the antimicrobial activity demonstrated in this study and others (Burkholder et al. 1944, Carrazzoni 1975, Huovinen \& Ahti 1986, Ahti et al. 1993, Lauterwein et al. 1995, Pereira et al. 1997, Honda \& Vilegas 1998, Yano-Melo et al. 1999, Donlan 2001, Falcão et al. 2004, Ribeiro et al. 2006, Moura et al. 2008).
Ranković et al. (2012) tested the antibacterial activity of usnic acid compared to streptomycin for Bacillus mycoides (ATCC 6462), B. subtilis (ATCC 6633), S. aureus (ATCC 25923), Escherichia coli (ATCC 25922), and Klebsiella pneumoniae (ATCC 13883). They observed that usnic acid obtained similar or stronger activity than the isolates tested with streptomycin. The MIC with Staphylococcus spp. were from $0.0008 \mathrm{mg} / \mathrm{mL}-0.5 \mathrm{mg} / \mathrm{mL}$, and with $S$. aureus (ATCC 25923), the MIC was $0.125 \mathrm{mg} / \mathrm{mL}$. The range found in this study was $0.0019 \mathrm{mg} / \mathrm{mL}$ to $0.25 \mathrm{mg} / \mathrm{mL}(\mathrm{n}=136)$. Manojlovic et al. (2012) determined MIC against B. mycoides (ATCC 6462), B. subtilis (ATCC 6633), S. aureus (ATCC 25923), E. coli (ATCC 25922), and K. pneumoniae (ATCC 13883), with values from $0.015 \mathrm{mg} / \mathrm{mL}$ to $1 \mathrm{mg} / \mathrm{mL}$. They also found the concentration of $0.125 \mathrm{mg} / \mathrm{mL}$ for S. aureus (ATCC 25923). Honda et al. (2010) determined MIC using usnic acid against Mycobacterium tuberculosis, with a value of $0.625 \mathrm{mg} / \mathrm{mL}$. Gupta et al. (2012) determined the MIC of L (-)-usnic acid against clinical isolates of MRSA (S. aureus MTCC-96 (SA-96)), and found inhibition from $25 \mathrm{mg} / \mathrm{mL}$ to $50 \mathrm{mg} / \mathrm{mL}$. Those values are much higher than those found in this study, as well as by Manojlovic et al. (2012) and Honda et al. (2010). Gupta et al. (2012) showed that the antimicrobial activity of usnic acid against MRSA occurs by rupturing the cell membrane. In regarding to toxicity, the authors also showed that usnic acid is safe in mice at concentrations of up to $100 \mathrm{mg} / \mathrm{kg}$. Segatore et al. (2012) evaluated usnic acid in combination with antimicrobials and observed the following: synergism with gentamicin, antag-

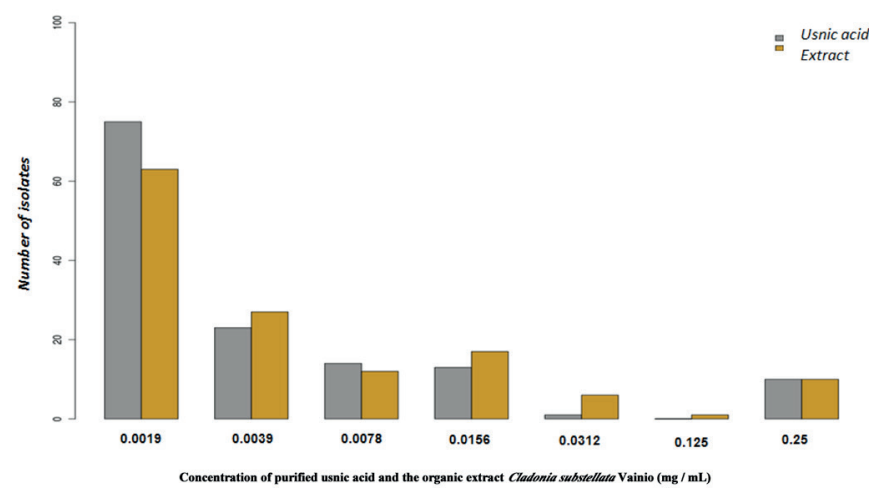

Fig.1. Antimicrobial effect. Comparison of the antimicrobial effect of the extract of Cladonia substelatta Vainio and purified usnic acid at different concentrations of $\mathrm{mg} / \mathrm{mL}$ for determination of minimum inhibitory concentration (MIC) and minimum bactericidal concentration (MBC), according to the Wilcoxon statistical test (Sampaio 2007).

Table 3. MIC $^{\mathrm{a}}$ and MBC $^{\mathrm{b}}$ of the organic extract Cladonia substellata Vainio and purified usnic acid

\begin{tabular}{lcc}
\hline Extract/fraction & $\begin{array}{c}\text { Mean of MIC and MBC in } \\
\text { biofilm-producing } \\
\text { Staphylococcus } \text { spp. }{ }^{\mathrm{c}, \mathrm{d}}\end{array}$ & $\begin{array}{c}\text { Mean of MIC and MBC in } \\
\text { non-biofilm-producing } \\
\text { Staphylococcus } \text { spp. }{ }^{\mathrm{c}, \mathrm{e}}\end{array}$ \\
\hline Organic extract & $0.65 \mathrm{mg} / \mathrm{mL}$ & $2.52 \mathrm{mg} / \mathrm{mL}$ \\
Usnic acid & $0.42 \mathrm{mg} / \mathrm{mL}$ & $2.71 \mathrm{mg} / \mathrm{mL}$
\end{tabular}

${ }^{a}$ Minimum inhibitory concentration, ${ }^{\mathrm{b}}$ minimum bactericidal concentration, ${ }^{\mathrm{c}}$ Phenotypic test; the assay was performed in 96-well polystyrene microplates, ${ }^{d} \mathrm{n}=19$ isolates, ${ }^{\mathrm{e}} \mathrm{n}=23$ isolates. 
onism with levofloxacin, unresponsiveness when used in combination with erythromycin, and variability when associated with oxacillin and clindamycin. The authors suggested usnic acid as a good candidate for an antimicrobial agent when used in combination with other commercially available drugs.

\section{Interaction of the organic extract of $C$. substellata and} purified usnic acid with the biofilm of Staphylococcus spp. consolidated and in formation and their relationship to the MIC and MBC

Of the 19 isolates of biofilm-producing Staphylococcus spp., one isolate was classified as coagulase-positive Staphylococcus, two as coagulase-negative Staphylococcus, two as $S$. intermedius, and 14 as $S$. aureus. The interaction of biofilm in formation and consolidated biofilm of Staphylococcus spp. against the organic extract of $C$. substellata and purified usnic acid was also evaluated (Table 3).

The antibacterial activity (MIC and MBC) of the organic extract of C. substellata and purified usnic acid against 19 isolates of biofilm-producing Staphylococcus spp. (one coagulase-positive Staphylococcus, two coagulase-negative Staphylococci, two S. intermedius, and 14 S. aureus) and 23 isolates of non-biofilm-producing $S$. aureus was determined (Table 4). It was observed that the organic extract of $C$. substellata and purified usnic acid had antimicrobial activity at lower concentrations $(0.65 \mathrm{mg} / \mathrm{mL}-0.42 \mathrm{mg} / \mathrm{mL})$ against biofilm-producing bacteria as compared to non-biofilm-producing isolates $(2.52 \mathrm{mg} / \mathrm{mL}-2.71 \mathrm{mg} / \mathrm{mL})$.

The organic extract of $C$. substellata and purified usnic acid at a concentration of $0.25 \mathrm{mg} / \mathrm{mL}$ inhibited biofilm formation in more than $37 \%$ of the Staphylococcus spp. strains. Furthermore, they interacted with the already established biofilm, reducing or destroying more than $47 \%$ of the isolates. Chifiriuc et al. (2009), evaluating in vitro inhibition of biofilm production in dental plaque by usnic acid, found that it selectively inhibited the development of biofilm by Gram positive bacteria and also the hemolytic properties of the bacteria, exhibiting the action of usnic acid with the intra- and inter-bacterial interface, signaling mechanisms based on quorum sensing and response dependent on the density of bacterial cells. This recommends usnic acid as a new active ingredient for a pharmaceutical formulation that could be used in the prevention and treatment of gingival and periodontal diseases.

Kim et al. (2011) also examined the inhibition of bio- film by usnic acid, as well as the antimicrobial efficacy and cytotoxicity of the compound. The authors showed the effectiveness of usnic acid as an antimicrobial to be used in the prevention of biofilm production by Staphylococcus spp. A study by Franconi et al. (2004) showed the ability of $(+)$-usnic acid to control biofilm formation by S. aureus and $P$. aeruginosa in laminar flow conditions by image analysis. The polymers loaded with (+)-usnic acid did not inhibit the initial cell attachment of $S$. aureus, but killed the bound cells, resulting in inhibition of biofilm production. Regarding $P$. aeruginosa, with use of the same polymers of $(+)$-usnic acid, there was biofilm formation in the laminar surface, but the morphology of the biofilm was altered, possibly indicating that (+)-usnic acid may interfere in the signaling pathways of bacteria and thereby inhibit or modify production of bacterial biofilm. Pompilio et al. (2013) evaluated the in vitro usnic acid antibacterial and antibiofilm activity against three strains of MSSA and three MRSA isolates from human patients with cystic fibrosis. They concluded that usnic acid shows activity against planktonic cells, is active against MRSA, and is capable of inhibiting biofilm formation. Grumezescu et al. (2011) also evaluated the antibiofilm activity of usnic acid incorporated into nanoparticles, and showed that they could be used as coating agents for different medical devices to prevent biofilm formation, including formation in patients with cystic fibrosis.

In this study, organic extract of $C$. substellata and usnic acid inhibited biofilm formation of Staphylococcus spp. This may have occurred due to establish bacterial death. Usnic acid and the organic extract of $C$. substellata, containing more than $90 \%$ usnic acid in its composition, inhibited biofilm already established for Staphylococcus spp. Usnic acid may also contain mechanisms that interact directly with already consolidated bacterial biofilms. In addition, it was possible to determine antimicrobial activity through bacterial death and/or bacterial inhibition (MIC and MBC), and to quantify the interaction of usnic acid directly with biofilm (in formation and that already established), which showed better antimicrobial activity against Staphylococcus spp. biofilm producers. In this study, it was observed that lower concentrations of usnic acid are needed to inhibit bacterial growth when compared to Staphylococcus spp. non-biofilm producers. This might enhance the action of usnic acid since biofilm does not impede its mechanism of action. The formation of bacterial biofilm provides the bacteria with resistant to antimicrobial agents, and this has

Table 4. Description of one hundred thirty-six Staphylococcus spp. isolates obtained in Brazil

\begin{tabular}{lcccc}
\hline Clinical source $\left(\mathrm{n}^{\mathrm{a}}\right)$ & Animal species (n) & Isolates (n) & City (State) & Period/Year \\
\hline Skin/pyodermatitis (86) & $\operatorname{Dogs}^{\mathrm{b}}(76)$ & 75 & Petrolina (PE) & 2011 to 2012 \\
& Cats $^{\mathrm{c}}$ (10) & 01 & Santa Maria (RS) & 1991 \\
& 10 & Petrolina (PE) & 2012 \\
External ear/otitis (50) & Dogs (49) & 24 & Petrolina (PE) & 2012 \\
& & 23 & Santa Maria (RS) & 1990 to 1995 \\
& & 01 & Santa Cruz do Sul (RS) & 1990 \\
& & 01 & Caçapava do Sul (RS) & 1990 \\
& Cats (01) & 01 & Petrolina (PE) & 2012
\end{tabular}

$\overline{\mathrm{a}}$ Total number of samples according to clinical source, ${ }^{\mathrm{b}}$ Canis familiaris, ${ }^{\mathrm{c}}$ Felis domesticus. 
been a concern in the search for new antimicrobials (Gilbert et al. 2003, Zhao et al. 2008). Usnic acid has great potential as a pharmaceutical and/or a pharmacological adjuvant for use in prevention of Staphylococcus spp. infections.

\section{CONCLUSIONS}

The organic extract of Cladonia substellata and purified usnic acid exhibited antimicrobial activity at low concentrations against Staphylococcus spp. that is resistant to conventional antibiotics.

Additionally, the substances inhibited biofilm formation by Staphylococcus spp. and showed greater efficacy against biofilm-producing isolates.

These characteristics are important and ought to be considered in regard to the drugs routinely used in clinical medicine, especially in the search for substances with pharmacological action on biofilm-producing bacteria and those resistant to various pharmacological groups.

We highlight the great potential of the organic extract of $C$. substellata and purified usnic acid in veterinary dermatology, mainly in the treatment of otitis and pyoderma caused by Staphylococcus spp. in dogs and cats.

Acknowledgements.- To Dr. Nicácio Henrique da Silva (UFPE) for their support in carrying out the chromatography analysis thin layer and isolation of usnic acid; to the graduate students Maria da Conceição Aquino, Carina Krewer, and Marielly Bastos Cavalcante (Univasf) for technical support; to Regina Wolf Queiroz and Ana Amélia Domingues Gomes, University Veterinary Hospital (HVU) of Univasf, for helping in specimen collection. To Brazilian agencies for science supporting: CAPES for a scholarship to JBM. ECP thanks CNPq (Brazilian Fostering Agency) for her research productivity grant. In addition, the authors thank Univasf, Labac/UFSM, and UFPE for use of the laboratory facilities, where this study was carried out, and for financial support of this project. This study was approved by the ethics committee: Univasf, protocol number 0002/121212.

\section{REFERENCES}

Aarestrup F.M., Seyfarth A.M., Emborg H.D., Pedersen K., Hendriksen R.S. \& Bager F. 2001. Effect of abolishment of the use of antimicrobial agents for growth promotion on occurrence of antimicrobial resistance in fecal Enterococci from food animals in Denmark. Antimicrob. Agents CH. 45:2054-2059.

Ahti T., Stenroos S. \& Xavier-Filho L. 1993. The lichen family Cladoniaceae in Paraíba, Pernambuco and Sergipe, northeast Brazil. Trop. Bryol. 7:5570.

Arciola C.R., Baldassari L. \& Montanaro L. 2001. Presence of icaA and icaD and slime production in a collection of Staphylococcal strains from catheter-associated infections. J. Clin. Microbiol. 39:2151-2156.

Ausubel F.M., Brent R., Kingston R.E., Moore D.D., Seidman J.G., Smith J.A. \& Struhl K. 1987. Current protocols in molecular biology. Greene Publishing Associates, John Wiley and Sons, New York.

Batista W.B., Platt W.J. \& Macchiavelli R.E. 1998. Demography of a shadetolerant tree in a hurricane-disturbed forest. Ecology 79:38-53.

Bauer A.W., Kirby W.M.M., Sherris J.C. \& Turck M. 1996. Antibiotic susceptibility testing by a standardized single disk method. Am. J. Clin. Pathol. 45:493-496.

Bemis D.A., Jones R.D., Hiatt L.E., Ofori E.D., Rohrbach B.W., Frank L.A. \& Kania S.A. 2006. Comparison of test to detect oxacillin resistance in Staphylococcus intermedius, Staphylococcus schleiferi, and Staphylococcus aureus isolates from canine hosts. J. Clin. Microbiol. 44:3374-3376.

Bornand V. 1992. Bacteriology and mycology of otitis externa in dogs. Schweiz, Arch, Tierheilkd. 134:341-348.

Cardoso M.J.L., Machado L.H.A., Melussi M., Zamarian T.P., Carnielli C.M.
\& Ferreira Júnior J.C.M. 2011. Dermatopatias em cães: revisão de 257 casos. Archs Vet. Sci. 16:66-74.

Burkholder P.R., Evans A.W., McVeigh I. \& Thornton H.K. 1944. Antibiotic activity of lichens. Proc. Natl Acad. Sci. USA 30:250-255.

Carrazzoni E.P. 1975. Estudo Químico de Liquens: Parmelia hababiana e Cladonia verticilaris. Tese para o Concurso de Livre-Docência em Química de Produtos Naturais do Departamento de Bioquímica da UFPE, Recife. 101p.

Carvalho E.A.B., Andrade P.P., Silva N.H., Pereira E.C. \& Figueiredo R.C.B.Q. 2005. Effects of usnic acid from Cladonia substellata on Trypanosoma cruzi in vitro: an ultrastructural study. Micron 36:155-161.

Chifiriuc M.C., Ditu L.M., Oprea E., Litescu S., Bucur M., Marutescu L., Enache G., Saviuc C., Burlibasa C., Trãistaru T., Tãnãse G. \& Lazãr V. 2009. In vitro study of the inhibitory activity of usnic acid on dental plaque biofilm. Rom Arch. Microbiol. Immunol. 68:215-22.

Cizman M. 2003. The use and resistance to antibiotics in the community. Int. J. Antimicrob. Agernts 21:297-307.

Cochietto M.S.N., Nimis P.L. \& Sava G. 2002. A review on usnic acid, an interesting natural compound. Revta Bras. Ciênc. Farm. 89:137-146.

CLSI 2008. Performance Standards for Antimicrobial Disk Susceptibility Tests for Bacteria Isolated from Animals; Approved Standard (M31-A3). 3rd ed. Clinical and Laboratory Standards Institute, Wayne, PA.

CLSI 2010. Performance Standards for Antimicrobial Susceptibility Testing: Twentieth Informational Supplement. CLSI Document M100-S20. Clinical and Laboratory Standards Institute, Wayne, PA.

Coelho S. de M. de O., Moraes R.A.M., Soares L. de C., Pereira I.A., Gomes L.P. \& Souza M.M.S. 2007. Resistance pattern and detection of mecA gene in oxacillin-resistant isolates of Staphylococcus aureus and Staphylococcus intermedius from animal and human samples. Ciência Rural 37:195-200.

Cole L.K., Kwochka K.W., Kowalski J.J. \& Hillier A. 1998. Microbial flora and antimicrobial susceptibility patterns of isolated pathogens from the horizontal ear and middle ear dogs with otitis media. J. Am. Vet. Med. Assoc. 212:534-538.

Culberson C.F. 1972. Improved conditions and new data for the identification of lichen products by a standardized thinlayer-chromatographic method. J. Chromatogr. 72:113-125.

Donlan R.M. 2001. Biofilms and device-associated infections. Emerg. Infect. Dis. 7:277-281.

Duijkeren E., Wolfhagen J.H.M., Box A.T.A., Herck M.E.O.C., Wannet W.J.B. \& Fluit A.C. 2004. Human-to-dog transmission of methicillin-resistant Staphylococcus aureus. Emerg. Infect. Dis. 10(12):2235-2237.

Eftekhar F. \& Speert D.P. 2009. Biofilm formation by persistent and non-persistent isolates of Staphylococcus epidermidis from a neonatal intensive care unit. J. Hosp. Infect. 71:112-116.

Falcão E.P., Silva N.H., Gusmão N.B., Ribeiro S.M. \& Pereira E.C. 2004. Atividade antimicrobiana de derivados fenólicos do líquen Ramalina soredio$s a$ (B. de Lesd) Laudron. Acta Bot. Bras. 18:911-918.

Fournet A., Ferreira M.E., de Arias A.R., De Ortiz S.T., Inchausti A., Yaluff G., Quilhot W., Fernandez E. \& Hidalgo M.E. 1997. Activity of compounds isolated from Chilean lchens against experimental cutaneous Leishmaniasis. Comp. Biochem. Phys. 116:51-54.

Franconi I., Norris P., Piozzi A., Donelli G. \& Stoodley P. 2004. Usnic acid, a natural antimicrobial agent able to bacterial biofilm formation on polymer surfaces. Antimicrob. Agents Chemother. 48:4360-4365.

Frank L.A., Kania S.A., Hnilica K.A., Wilkes R.P. \& Bemis D.A. 2003. Isolation of Staphylococcus schleiferi from dogs with pyoderma. J. Am. Vet. Med. Assoc. 222:451-454.

Frey Y., Rodriguez J.P., Thomann A., Schwendener S. \& Perreten V. 2013. Genetic characterization of antimicrobial resistance in coagulase-negative staphylococci from bovine mastitis milk. J. Dairy Sci. 96:2247-2257.

Fuda C.C.S., Fisher J.F. \& Mobashery S. 2005. B-Lactam resistance in Staphylococcus aureus: the adaptive resistance of a plastic genome. Cell Mol. Life Sci. 62:2617-2633.

Gilbert P., McBain A.J. \& Rickard A.H. 2003. Formation of microbial biofilm in hygienic situations: a problem of control. Biodeter. Biodegr. 51:245-248. 
Ghidini F., Piancastelli C., Taddei S., Gandolfo E., Cavirani S. \& Cabasse C.S. 2011. Antibiotic sensitivity of bacterial isolates from cases of canine dermatitis. New Microbiologica 34:403-408.

Grisold A.J., Leitner E., Mühlbauer G., Marth E. \& Kessler H.H. 2002. Detection of methicillin-resistant Staphylococcus aureus and simultaneous confirmation by automated nucleic acid extraction and Real-Time PCR. J. Clin. Microbiol. 40:2392-2397.

Gupta V.K., Verma S., Gupta S., Singh A., Pal A., Srivastava P.K., Singh S.C. \& Sarokar M.P. 2012. Membrane-damaging potential of natural L-(-)-usnic acid in Staphylococcus aureus. Eur. J. Clin. Microbiol. Infect. Dis. 31:3375-3383.

Grumezescu A.M., Saviuc C., Chifiriuc M.C., Hristu R., Mihaiescu D.E., Balaure P., Stanciu G. \& Lazar V. 2011. Inhibitory activity of Fe(3) O(4)/oleic acid/usnic acid-core/shell/extra-shell nanofluid on S. aureus biofilm development. IEEE Trans Nanobiosci. 10:269-274.

Hiramatsu K. 1995. Molecular evolution of MRSA. Microbiol. Immunol. 39: 531-543.

Hoekstra K.A. \& Paulton R.J.L. 2002. Clinical prevalence and antimicrobial susceptibility of Staphylococcus aureus and Staphylococcus intermedius in dogs. J. Appl. Microbiol. 93:406-413.

Honda N.K., Pavan F.R., Coelho R.G., Andrade Leite S.R., Micheletti A.C., Lopes T.I., Misutsu M.Y., Beatriz A., Brum R.L. \& Leite C.Q.F. 2010. Antimycobacterial activity of lichen substances. Phytomedicine 17:328-332.

Honda N.K. \& Vilegas W. 1998. A química dos liquens. Quím. Nova. 21:6.

Huerta B., Maldonado A., Ginel P.J., Tarradas C., Gómez-Gascón L. \& Astorga R.J. 2011. Risk factors associated with the antimicrobial resistance of staphylococci in canine pyoderma. Vet. Microbiol. 150:302-308.

Huovinen K. \& Ahti T. 1986. The composition and contents of aromatic lichen substances in the genus Cladonia section Unciales. Ann. Bot. Fenn. 23:173-188.

Ingólfsdóttir K. 2002. Usnic acid. Phytochemistry 61:729-736.

Junco M.T.T. \& Barraza J.T.M. 2002. Identification and antimicrobial susceptibility of coagulase positive Staphylococci isolated from healthy and dogs suffering from otitis externa. J. Vet. Med. B, Infect. Dis. Vet. Public. Health 49:419-423.

Katayama T., Ikeda Y., Handa M., Tamatani T., Sakamoto S., Ito M., Ishimura Y. \& Suematsu M. 2000. Immunoneutralization of glycoprotein Ib $\alpha$ attenuates endotoxin-induced interactions of platelets and leukocytes with rat venular endothelium in vivo. Circ. Res. 86:1031-1037.

Kateete D.P., Kimani C.N., Katabazi F.A., Okeng A., Okee M.S., Nanteza A., Joloba M.L. \& Najjuka F.C. 2010. Identification of Staphylococcus aureus: DNase and mannitol salt agar improve the efficiency of the tube coagulase test. Ann. Clin. Microbiol. Antimicrob. 9:23.

Kawakami T., Shibata S., Murayama N., Nagata M., Nishifuji K., Iwasaki T. \& Fukata T. 2010. Antimicrobial susceptibility and methicillin resistance in Staphylococcus pseudintermedius and Staphylococcus schleiferi subsp. coagulans isolated from dogs with pyoderma in Japan. J. Vet. Med. Sci. 72:615-619.

Kim S., Greenleaf R. \& Miller M.C. 2011. Mechanical effects, antimicrobial efficacy and cytotoxicity of usnic acid as a biofilm prophylaxis in PMMA. J. Mater. Sci. Mater. Med. 22:2773-2780.

Kikuchi M. \& Ohshima K. 2004. Cervical lymphadenopathy, fever and leukopenia (histiocytic-necrotizing lymphadenitis or Kikuchi disease). Pathology Case Reviews 9:199-205.

Koneman E.W., Allen S.D. \& Janda W.M. 1997. Antimicrobial Resistance: color atlas and text book of diagnostic microbiology. 5th ed. Lippincott Raven Publishers, Philadelphia.

Lauterwein M., Oethinger M., Belsner K., Peters T. \& Marre R. 1995. In vitro activities of lichen secondary metabolites vulpinic acid (+)-usnic acid, and (-)-usnic acid against aerobic and anaerobic microorganisms. Antimicrob. Agents Chemother. 39:2541-2543.

Leite C.A.L. 2000. As otites de cães e gatos. I. Epidemiologia. Cães e Gatos 93:22-26.

Lilenbaum W., Veras M., Blum E. \& Souza G.N. 2000. Antimicrobial susceptibility of Staphylococci isolated from otitis externa in dogs. Lett. Appl. Microbiol. 31:42-45.
Livorsi D.J., Crispell E., Satola S.W., Burd E.M., Jerris R., Wang Y.F. \& Farley M.M. 2012. Prevalence of blaZ gene types and the inoculum effect with cefazolin among bloodstream isolates of methicillin-susceptible Staphylococcus aureus. Antimicrob. Agents Chemother. 56:4474-4477.

Manojlovic N., Rankovic B., Kosanic M., Vasiljevic P. \& Stanojkovic T. 2012. Chemical composition of three Parmelia lichens and antioxidant, antimicrobial and cytotoxic activities of some their major metabolites. Phytomedicine 19:1166-1172.

Meneses A.M.C., Ardoso M.J.L., Franco S.R.V.S. \& Abe KC. 2000. Ocorrência das dermatopatias em cães e gatos. Revta Bras. Ciênc. Vet. 7(Suppl.2):20.

Meng J. \& Doyle M.P. 1998. Antibiotic resistance of Escherichia coli 0157:H7 and 0157:NM isolated from animals, food and humans. J. Food Prot. 61:1511-1514.

Merino N., Toledo-Arana A., Vergara-Irigaray M., Valle J., Solano C., Calvo E., Lopez J.A., Foster T.J., Penadés J.R. \& Lasa I. 2009. Protein A-mediated multicellular behavior in Staphylococcus aureus. J. Bacteriol. 191(3):832-843.

Merino S., Gavin R., Vilches S., Shaw J.G. \& Tomas J. 2003. Colonizition factor (production of lateral flagella) of Mesophilic Aeromonas spp. is inactive in Aeromonas salmonicida strains. Appl. Environ. Microbiol. 69:663-667.

Moura M.P.S., Lira M.C.B. \& Magalhães N.S.S.M. 2008. Validation of a UV-spectrophotometric analytical method for the determination of usnic acid in liposomes. Braz. J. Pharm. Sci. 44:4.

Muller E.E., Freitas J. \& Alfieri A.A. 1986. Isolamento, caracterização e susceptibilidade a antimicrobianos de estafilococos coagulase-positivos $(S$. aureus e intermedius) de cães com lesões de pele, na região de Londrina. Seminário de Ciências Agrárias, Universidade Estadual de Londrina, Londrina/PR, 7:34-37.

Müller K. 2001. Pharmaceutically relevant metabolites from lichens. Appl. Microbiol. Biotechnol. 56:9-16.

Nóbrega N.A., Ribeiro S.M.A., Pereira E.C., Marcelli M.P., Martins M.C.B., Falcão E.P.S., Gusmão N.B. \& Silva N.H. 2012. Production of phenolic compounds from immobilized cells of the lichen Pamotrema andinum (Müll. Arg.) Hale and evaluation of antimicrobial activity. Acta Botanica Brasilica 26:101-107.

Nostro A., Roccaro A.S., Bisignano G., Marino A., Cannatelli M.A., Pizzimenti F.C., Cioni P.L., Procopio F. \& Blanco A.R. 2007. Effects of oregano, carvacrol and thymol on Staphylococcus aureus and Staphylococcus epidermidis biofilms. J. Med. Microbiol. 56:519-523.

Oliveira D. 2011. Methicillin-resistance in Staphylococcus aureus is not affected by the overexpression in trans of the mecA gene repressor: a surprising observation. PLOS ONE [1932-6203]6:8.

Oliveira G.A., Levy C.E. \& Mamizuka E.M. 2000. Study of the resistance profile of 626 strains of Staphylococcus aureus isolated in 25 Brazilian hospitals from September/95 to June/97. J. Bras. Patol. 36:147-156.

Oliveira L.C., Medeiros C.M.O., Silva I.N.G., Monteiro A.J. \& Leite C.A.L. 2005. Antimicrobial sensitivity of bacteria from otitis externa in dogs. Arq. Bras. Med. Vet. Zootec. doi: 10.1590/S0102-09352005000300021

Oliveira L.C., Brilhante R.S.N., Cunha M.A.S. \& Carvalho C.B.M. 2006. Profile of microorganisms isolated from dogs with associated media and extern otitis. Arq. Bras. Med. Vet. Zootec. 58:1009-1017.

Pereira E.C. 1998. Produção de metabólitos por espécies de Cladoniaceae (líquen), a partir de imobilização celular. Tese de Doutorado em Botânica, Universidade Federal Rural de Pernambuco, Recife. 238p.

Pereira E.C., Silva N.H., Campos-Takaki G.M., Xavier-Filho L., Legaz M.E. \& Vicente C. 1997. Antimicrobial activity of biological active compounds from the lichen Caldonia crispatula. Bolm Ecotropica Ecosistemas Trop. 31:9-19.

Perillo J., Ceccarelli D., Spagnoletti M., Lollai S., Cappuccinelli P. \& Colombo M.M. 2012. Molecular characterization of enterotoxigenic and borderline oxacillin resistant Staphylococcus strains from ovine milk. Food Microbiol. 32:265-273.

Pompilio A., Pomponio S., Vincenzo V.D., Crocetta V., Nicoletti M., Piovano M., Garbarino J.A. \& Bonaventura G.D. 2013. Antimicrobial and antibiofilm activity of secondary metabolites of lichens against methicillin- 
resistant Staphylococcus aureus strains from cystic fibrosis patients. Future Microbiol. 8:281-292.

Quinn P.J., Markey B.K., Carter M.E., Donnelly W.J. \& Leonard F.C. 2005. Microbiologia Veterinária e Doenças Infecciosas (Tradução de Weiss L.H.N. \& Weiss R.D.N.). Artmed, Porto Alegre.

R Core Team 2012. R: a language and environment for statistical computing. R Foundation for Statistical Computing, Vienna, Austria.

Ranković B., Kosanić M., Stanojković T., Vasiljević P. \& Manojlovic N. 2012. Biological activities of Toninia candida and Usnea barbata together with their norstictic acid and usnic acid constituents. Int. J. Mol. Sci. 13:14707-14722.

Rao J.G., Qamruddin A.O., Hassan I.A., Burnie J.P. \& Ganner M. 2002. Cluster of clinical isolates of epidemic methicillin-resistant Staphylococcus aureus (EMRSA) with a negative deoxyribonuclease (DNase) test-implications for laboratory diagnosis and infection control. J. Hosp. Infect. 51:238-239.

Ribeiro S.M., Pereira E.C., Gusmão N.B., Falcão E.P. \& Silva N.H. 2006. Produção de metabólitos bioativos pelo líquen Cladonia substellata Vainio, Brasil. Acta Bot. Bras. doi: 10.1590/S0102-33062006000200003

Reis J.C. 1998. Estatística Aplicada à Pesquisa em Ciência Veterinária. Luci Artes Gráficas Ltda, Olinda.

Rochleder F. \& Heldt W. 1996. Ann. Chem. 48:1. In: Huneck S. \& Yoshimura I. 1843. Identification of Lichen Substances. Springer-Verlag, Berlin.

Sampaio I.B.M. 2007. Estatística Aplicada à Experimentação Animal. 3aㅡ ed. Editora FepMVZ, Belo Horizonte.

Santos R.R. 2007. Sensitivity in vitro of the microbiota of the ear of dogs with otitis externa to five antimicrobials. Acta Scient. Vet. 35:433-435.

Sawant A.A., Gillespie B.E. \& Oliver S.P. 2009. Antimicrobial susceptibility of coagulase-negative Staphylococcus species isolated from bovine milk. Vet. Microbiol.16:73-81.

Schwarz S., Silley P., Simjee S., Woodford N., Van Duijkeren E., Johnson A.P. \& Gaastra W. 2010. Assessing the antimicrobial susceptibility of bacteria obtained from animals. Vet. Microbiol. 24(141):1-4.

Schlotter K., Hotzel H., Ehricht R., Pfeffer M., Moneckes S. \& Donat K. 2013. Phenotyping and microarray based genotyping of the antibiotic resistance of MRSA and MSSA from quarter milk samples of clinically healthy dairy cows. Berl. Münch. Tierärztl. Wochenschr. 126:37-45.
Scott D.W., Miller W.H. \& Griffin C.E. 2001. Small Animal Dermatology. 6th ed. W.B. Saunders, Philadelphia.

Segatore B., Bellio P., Setacci D., Brisdelli F., Piovano M., Garbarino J.A., Nicoletti M., Amicosante G., Perilli M. \& Celenza G. 2012. In vitro interaction of usnic acid in combination with antimicrobial agents against methicillin-resistant Staphylococcus aureus clinical isolates determined by FICI and $\Delta$ E model methods. Phytomedicine 19:341-347.

Shome B.R., Mitra S.D., Bhuvana M., Krithiga N., Velu D., Shome R., Isloor S., Barbuddhe S.B. \& Rahman H. 2011. Multiplex PCR assay for species identification of bovine mastitis pathogens. J. Appl. Microbiol. 111:1349-1356.

Tanner M.A., Everett C.L. \& Youvan D.C. 2000. Molecular phylogenetic evidence for noninvasive zoonotic transmission of Staphylococcus intermedius from a canine pet to a human. J. Clin. Microbiol. 38:1628-1631.

Vandžurová A., Backor P., Javorský P. \& Pristas P. 2013. Staphylococcus nepalensis in the guano of bats (Mammalia). Vet. Microbiol.164:116-122. doi: 10.1016/j.vetmic.2013.01.043

Vasudevan P., Nair M.K.M., Annamalai T. \& Venkitanarayanan K.S. 2003. Phenotypic and genotypic characterization of bovine mastitis isolates of Staphylococcus aureus for biofilm formation. Vet. Microbiol. 92:179185.

Venkataramana D. \& Krishna K. 1992. High-performance liquid chromatographic determination of usnic acid in plasma. J. Chromatogr. 575:167170.

Wade K.A., Pounder J.I., Cloud J.L. \& Woods GL. 2005. Comparison of six methods of extracting Mycobacterium tuberculosis DNA from processed Sputum for testing by quantitative Real-time PCR. J. Clin. Microbiol. 43:2461-2473.

Yano-Melo A.M., Vicente C. \& Xavier-Filho L. 1999. Influence of Cladonia substellata Vainio extracts and usnic acid on germination and growth of Allium cepa L. seedlings. Trop. Bryol. 16:11-15.

Zhao Q., Liu Y., Wang C., Wang S., Peng N. \& Jeynes C. 2008. Reduction of bacterial adhesion on ion-implanted stainless steel surfaces. Med. Engin. Physics 30:341-349.

Ziebuhr W., Hennig S., Eckart M., Kränzler H., Batzilla C. \& Kozitskaya S. 2006. Nosocomial infections by Staphylococcus epidermidis: how a commensal bacterium turns into a pathogen. Int. J. Antimicrob. Agents 28(Suppl.1):S14-20. 